\title{
RENEWABLE ENERGY BASED MICRO-GRID SYSTEM FOR POWER QUALITY IMPROVEMENT
}

\author{
S. JANARTHANAN ${ }^{1} \&$ N. MANOHARAN ${ }^{2}$ \\ ${ }^{1}$ Assistant Professor, EEE (M), AMET University, Chennai, Tamilnadu, India \\ ${ }^{2}$ Rector, AMET University, Chennai, Tamil Nadu, India
}

\begin{abstract}
In recent years the microgrid had produced more power and utilized in the various application. The linear and non-linear load is used in grid-connected PV based converter system. The novel control strategy used to offer the possibility to inject electrical energy from the different renewable sources and on the other hand to improve the power quality in the same microgrid. The multilevel inverter connected in between the micro and main grid for study the power quality such as harmonic compensation, power factor correction, THD (total harmonic distortion), voltage and current balancing. The proposed topology has been implemented and results obtained by using MATLAB/SIMULINK.

KEYWORDS: THD, MATLAB/SIMULINK, Multilevel Inverter
\end{abstract}

Received: Oct 06, 2017; Accepted: Oct 26, 2017; Published: Jan 30, 2018; Paper Id.: IJMPERDFEB2018106

\section{INTRODUCTION}

The renewable energy based microgrid system produce as much power for many application U. K. Renduchintala and Chengzong Pang (2016). The microgrid had to store the power and transferred into various locations. The solar-based system produces the dc power and is converted into alternating current by using the inverter Salimbeni, et, al. The five-level three-phase inverter circuit is designed by controlling the voltage and reduce the harmonics. The Distributed Energy Resources M. I. Milanés et al. (2016), D. Tran and A. M. Khambadkone (2013) Synthesis, growth and characterisation of novel semi-organic nonlinear optical potassium boro-succinate (KBS) single crystals Sare one of the power generations systems in the small-scale range such as photovoltaic cell, wind energy generation system or hydro energy. The application of multifrequency airborne electromagnetics to iron ore exploration.

The proposed paper has various chapters. In chapter 1 introduction of the proposed converter, inverter and controller In chapter 2 explains about the proposed method. In chapter 3 explains the simulation results and chapter 4 conclusion of the proposed method.

\section{PROPOSED METHOD}

The proposed solar based inverter has produced the power reduces the voltage mitigation, and total harmonic distortion is reduced and use the active power controller. Reactive power optimization using firefly algorithm Kannan et al. (2015) for power quality improvement. The block diagram of proposed circuit topology is shown in figure 1. Single Input Fuzzy Logic Controller Based SVC for Dynamic Performance Enhancement of Power Systems Subramanian, D. D. P. (2014), N. Kiruthika (2015) for improving power quality 
and reliability.

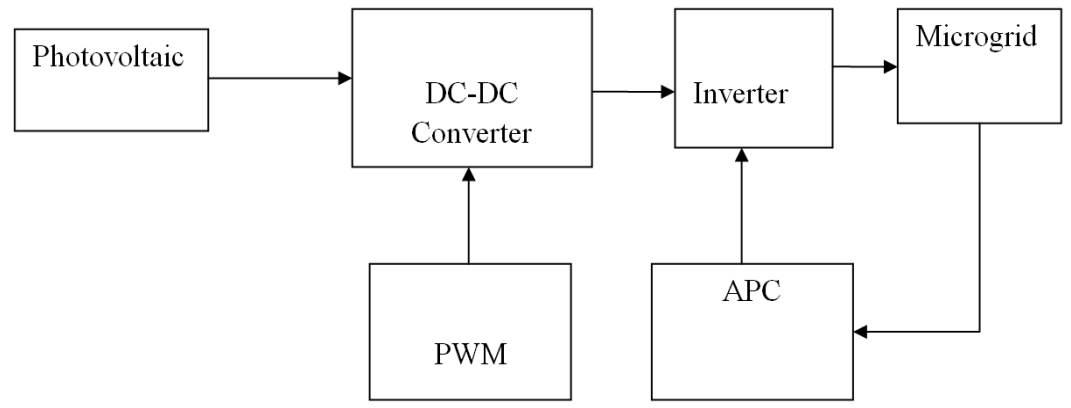

Figure 1: General Block Diagram of Proposed Method

\section{SIMULATION RESULTS}

The overall simulation circuit is shown in figure 2. The dc link voltage is shown in figure 3 . The output voltage and current waveform of a linear load are shown in figure 4. The total harmonic distortion of a linear load is shown in figure 5. The power factor correction of a linear load is shown in figure 6 Oscillating Water Column (OWC) Wave Power Caisson Breakwaters, the Present Status, Need for New Developments, and the Problems Ahead voltage and current waveform of a nonlinear load is shown in figure 7 . The total harmonic distortion of a nonlinear load is shown in figure 8.

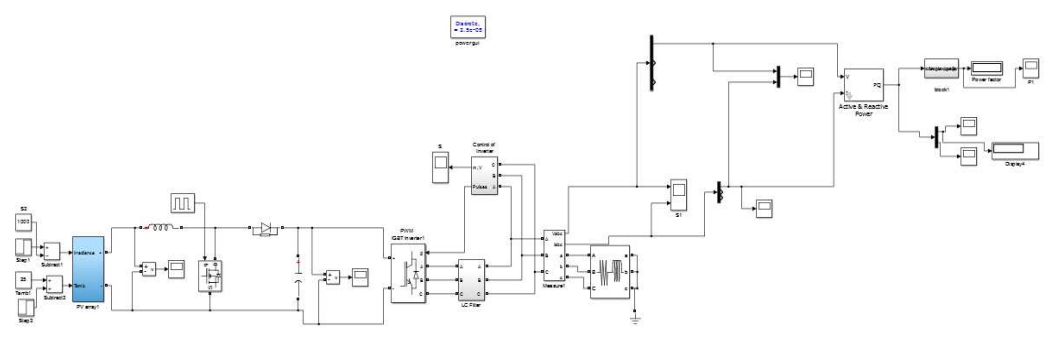

Figure 2: Overall Simulation Diagram

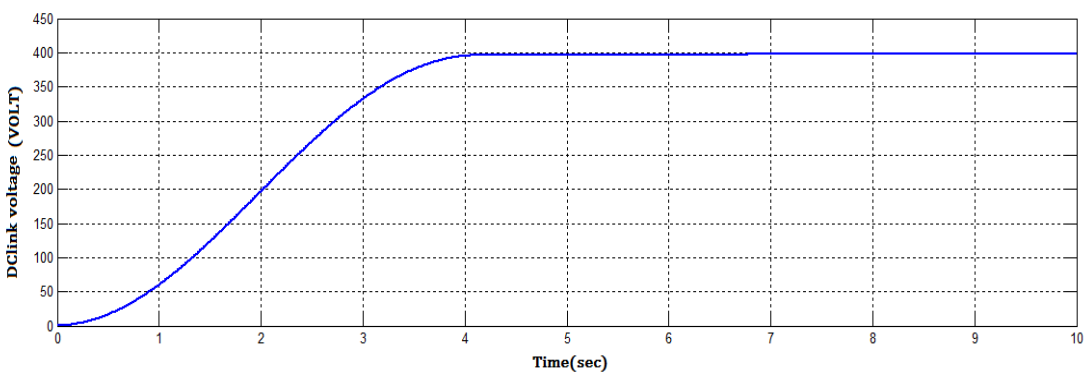

Figure 3: DC Link Voltage

Figure shows the output voltage of boost converter which is fed as inverters input and the voltage conversion ratio is quite high. Input voltage from PV is boosted to $400 \mathrm{~V}$ and the boost ratio is 1:4. 

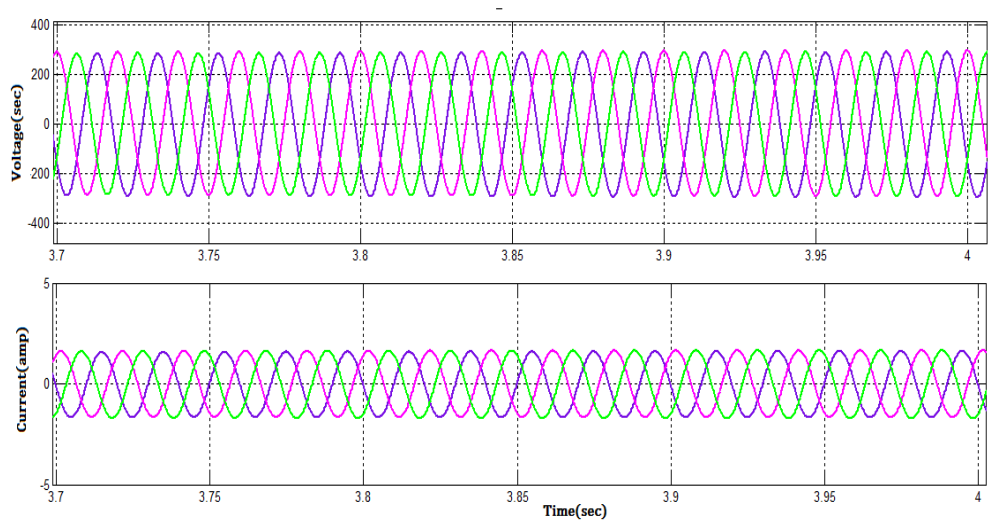

Figure 4: Output Voltage and Current Waveform of Linear Load

Figure shows load voltage and current of grid connected PV inverter micro grid system in the presence of linear load. Load value is kept at a nominal value and the produced output voltage is $230 \mathrm{~V}$ rms.

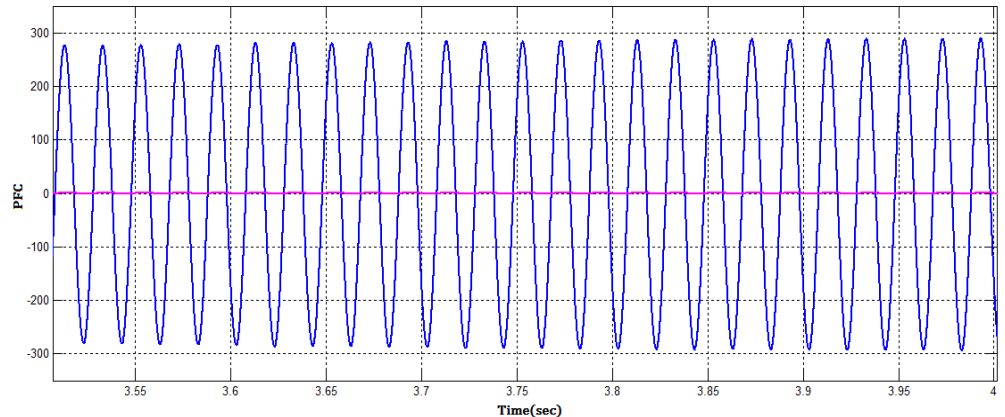

Figure 5: Power Factor Correction of Linear Load

Figure shows power factor correction waveform at load side in the presence of linear load, it is clear that PFC is unity and the current waveform is sinusoidal and follows the load voltage.

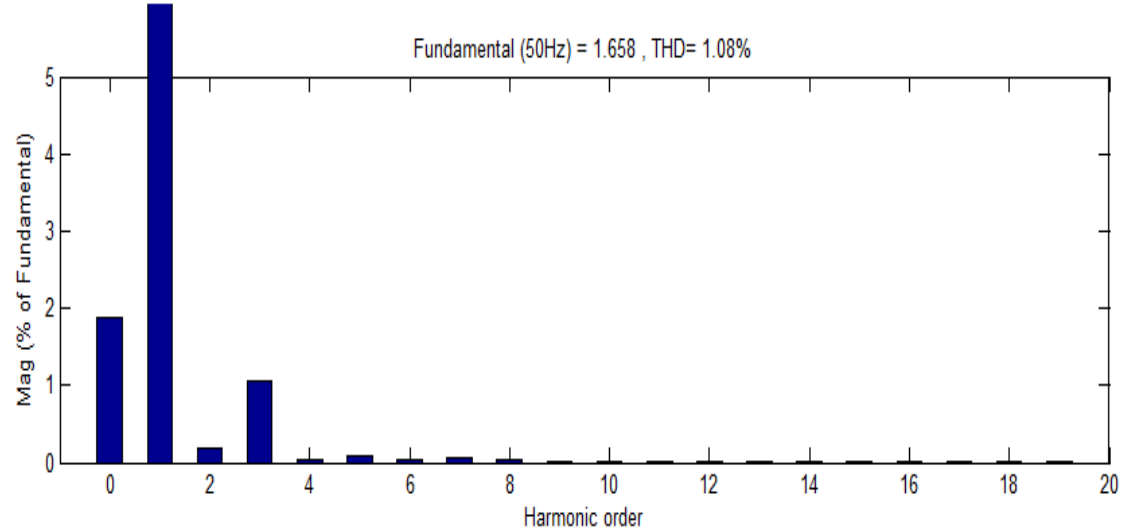

Figure 6: Total Harmonic Distortion Of Linear Load

Figure shows power quality enhancement of proposed PV inverter system in the presence of linear load, it is clear that THD in load voltage is less and well within standards set by IEEE-IEC. 

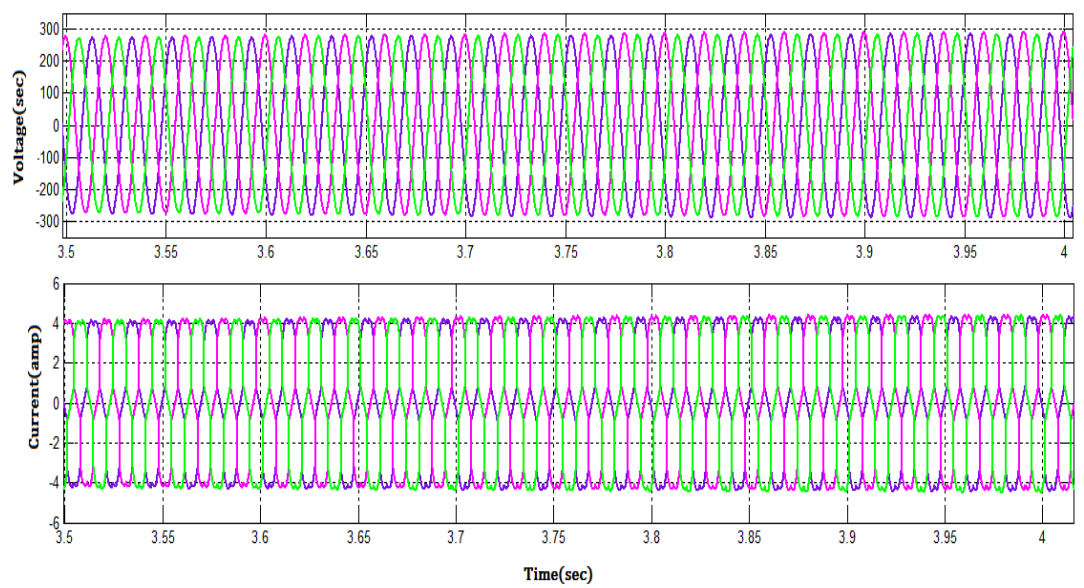

Figure 7: Voltage and Current Waveform of Nonlinear Load

Figure shows load voltage and current of grid connected PV inverter micro grid system in the presence of linear load. Load value is kept at a nominal value and the produced output voltage is $230 \mathrm{~V}$ rms.

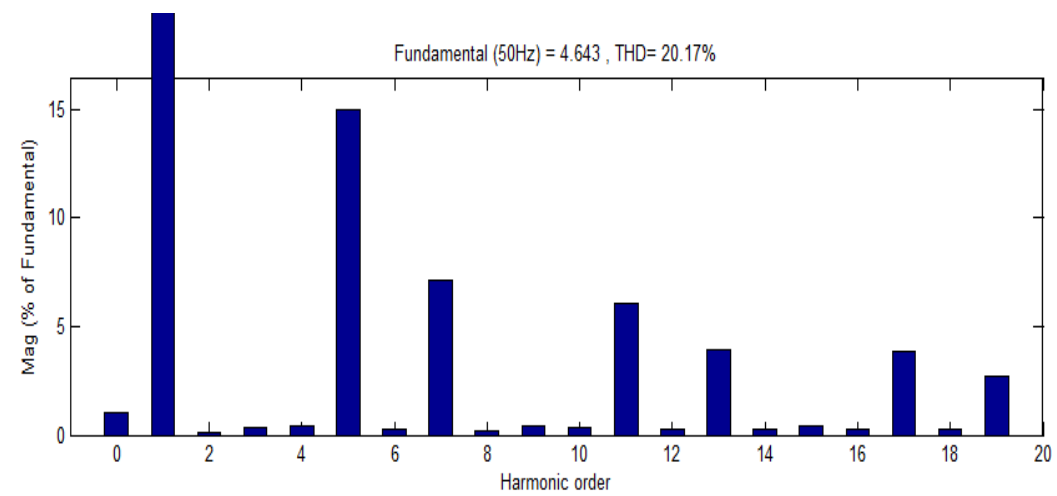

Figure 8: Total Harmonic Distortion of Nonlinear Load

Figure shows power quality enhancement of proposed PV inverter system in the presence of non linear load, THD in load voltage is reduced to $20.17 \%$ with non linear load with APC control in comparison with existing grid connected system.

\section{CONCLUSIONS}

This paper presents the high concert of DC-DC converter based on power inverter for microgrid applications.[9] To mographic seismic inversion of a paleochannel system reduces the voltage harmonics, voltage unbalance and also improve the performance of microgrid system. The use of linear and non-linear load is not affected by the voltage level of the inverter. The proposed five-level three-phase inverter for reducing the harmonic and improve the performance using the active power control.

\section{REFERENCES}

1. U. K. Renduchintala and Chengzong Pang (2016), "Neuro-fuzzy based UPQC controller for Power Quality improvement in the micro grid system," IEEE/PES Transmission and Distribution Conference and Exposition (T\&D), Dallas, TX, 2016, pp. $1-5$. 
2. Salimbeni, et, al (2016), "Integration of active filter and energy storage system for power quality improvement in microgrids," International Symposium on Power Electronics, Electrical Drives, Automation and Motion (SPEEDAM), Anacapri, pp. 709-714.

3. M. I. Milanés et al. (2016), "Local energy micro-storage systems in smart communities with active, reactive and harmonic control," IEEE 16th International Conference on Environment and Electrical Engineering (EEEIC), Florence, pp. 1-5.

4. D. Tran and A. M. Khambadkone (2013), "Energy Management for Lifetime Extension of Energy Storage System in Micro-Grid Applications," in IEEE Transactions on Smart Grid, vol. 4, no. 3, pp. 1289-1296, Sept. 2013.

5. Kannan et al. (2015). Reactive power optimization using firefly algorithm. In Power Electronics and Renewable Energy Systems (pp. 83-90). Springer India.

6. Subramanian, D. D. P. (2014). Design of a Single Input Fuzzy Logic Controller Based SVC for Dynamic Performance Enhancement of Power Systems.

7. N. Kiruthika (2015), “An advanced synchronous reference frame control on reduced switch unified power quality conditioner for harmonics reduction for distribution load" International Journal of MC Square Scientific Research Vol.7, No.1 
